\title{
Bureaucratic Reforms in Administering Government Based Electronic Government
}

\author{
Dita Fisdian Adni \\ Islamic University of Riau \\ Pekanbaru,Indonesia \\ ditafisdianadni@soc.uir.ac.id
}

\begin{abstract}
Information technology plays a very significant role and become an essential requirement in all aspects, one of them in terms of public service. It is characterized by the increasingly easy to find public service based technology. The provision of services to the community by bringing the principles of electronic government (e-gov) provides a great space for the institution to provide the best service in the forms of creative innovation. With the electronic government (egov) is expected to improve the quality of public services. The development of information technology in government is something that is encouraging. Of course, electronic government (e-gov) will not be such a big contribution to public services by the government if the role of human resources is not optimized. The development of electronic government (e-gov) apparently not free from defects. Constraints can be identified can be seen from two sides. The first can be seen from the government side and the second can be seen from the public. Other than that encountered in the implementation of e-government can also be seen from three aspects: cultural, aspects of leadership and infrastructure aspects.
\end{abstract}

Keywords- Bureaucratic Reforms, Information Technology, Electronic Government and Public Services.

\section{INTRODUCTION}

\section{Background}

Reform of the bureaucracy is one agenda that can not be separated from regional autonomy. Because of regional autonomy gives authority to the regions to independently promote a democratic and fair society, both in economic, social, cultural and political. In carrying out regional autonomy, needed an efficient bureaucracy, creative, innovative, professional and able to respond to the challenges of change.

Bureaucratic reform is a means to make the administrative system into a more effective instrument for social change, as well as a better instrument in creating political equality, social justice, as well as economic growth. Meanwhile, as a process of bureaucratic reform can be seen as a change in practices, the behavior and bureaucratic structures that have been established. Reform of the bureaucracy become a very important part in achieving good governance. One of the things that are important in good governance is on improving the quality of public services.

The application of the concept of good governance requires a fundamental change in the practice of governance structurally, functionally and culturally. Changes of government into governance requires a change of mindset and orientation of the bureaucracy that originally served the interests of the rulers changed to improve the quality of public services or serve the public.

Services carried out by the State to its citizens is a mandate contained in the Constitution of 1945 and clarified in Law Number 25 Year 2009 Challenge of Public Service. According to Law No. 25 of 2009 on the Services Publik ${ }^{[1]}$, the Public Service is an activity or series in order to meet the needs of the service in accordance with the laws of every citizen and resident in the goods, services, and / or administrative services provided by the service providers public.

Public services are at present increasingly become an interesting issue on the grounds that the quality of public service bureaucracies work has vast implications on various aspects of the lives of many people. In the life of the state, the government has a function as a provider of a wide range of public services that are needed by the community, ranging from service in the form of arrangement or other services in order to meet the needs of society in various fields such as health, education and others.

Realization of quality services to the community in the sense of service that is fast, accurate and fair is the hope for the organizations / agencies / institutions which run public services. Therefore, it is necessary to improve public services related to improved methods and procedures of public services. One of them attempts to change towards the better in terms of public services is one of the functions of government is to optimize the use of information technology.

Utilization of current technology is something that is unavoidable because of the need of information very quickly and precisely into a core needs in all aspects. One 
emerging technology is a web-based technology that is often called the Internet. This technology has been used in various fields of good governance, health, education, business and others. Internet technology has now been ingrained to be used optimally. The existence of this technology is expected to be the answer to leveling speed of service, a progress if the government started to adopt the technology in question as the main infrastructure of public services.

In the present era of information technology, public services face enormous challenges. This relates to the relationship between the countries with the market, the state and its citizens and the market with the citizens. Formerly the country positions itself as the most dominant in terms of the implementation of the public service. Markets and citizens will inevitably have to accept the conditions of public service that is already available. Many citizens are disappointed with the public service siding against certain groups, communication apparatus built by service providers are not friendly and tend to kink or ineffective.

Along with the times, the conditions of public services provided criticism from various parties that aim to improve the quality of communication and the management of the service, given that not all citizens can enjoy the accessibility of effective public services. Whereas as a mandate contained in legislation, public services should reach all layers without exception and keep the service ethic.

Quality of service is very low seen in almost all aspects of the public service, both in the aspect of the services and administrative services. To overcome these problems, and in line with the development of electronic technology aspects of information, one of the efforts that can be done is by using an electronic network. It is also based on the fact that people are getting used to it. Internetbased network that is used by the government known as electronic government (e-gov).

According to Kurniawan, terminology electronic government (e-gov) can be defined as a set of concepts to all the action in the public sector (both at the level of the Central Government and Local Government) involving information and communication technology in order to optimize the process of public service that is efficient, transparent and effective (in Hardiyansyah, 2006:107). Information and communication technologies are used such as email, WAN (Wide Area Network), the Internet, mobile computing devices (HP, laptop, PDA) and a variety of other technologies that serve to disseminate information and provide electronic services in various forms.[2]

Generally Abidin deciphering E-Government as management information systems and Internet-based community services. This service is provided by the government to the people. By utilizing the Internet, it would appear very much the development of government services to the public which enables the active role of society in which people are expected to independently carry out the registration of licensing, monitoring the process of completion, do directly for each licensing and other public services. All this with the help of internet technology will be done from anywhere and at anytime (in Hardiyansyah, 2011:108).[3]

A.S. Hikam, former Minister of Research and Technology, said that e-government is an electronicization of government services to citizens or citizens. In addition, e-government is also a process for democratization, with egovernment, also means cutting long bureaucratic lines. While the objective of e-government itself is to increase citizen access to public services of the government, increase public access to government information sources, handle public complaints and equality of service quality that can be enjoyed by all citizens. With e-government, there must be standardization of service quality that can be enjoyed by society (Kompas, 18/05/2005).[4]

From the above notions, the core of e-government is a process of using information technology as a tool to help run the government system more efficiently. Therefore, in view of e-government, we are not fazed by the element "e" per se, but more importantly is the process of government itself (Hardiyansyah, 2011:109). [5]

With regard to the description above, there are two main things that can be taken in terms of e-government, the first is the use of information technology (one of them is internet) as a tool, and the second, the purpose of utilization so that government can run more efficiently. With information technology / internet, the whole process or procedures in the administration can be passed quickly origin used appropriately.

\section{DISCUSSION}

\section{Adoption of Electronic Government (E-Gov)}

Public services in almost all developed countries like the United States and Europe have relied on electronic government technology. That is to say, all public services are accessible to all citizens are integrated quickly. The purpose of the implementation of e-government is one of them is to create good governance where government services are transparent, accountable and corruption-free.

By Indrajit (2006;8) [6], clearly the two major countries in the forefront in implementing the concept of egovernment, namely the US and the UK through Al Gore and Tony Blair, has been clearly and in detail describe the benefits gained by implementing konseop e-government for a State, among others:

- Improving the quality of government services to its stakeholders (community, business and industry), 
especially in terms of performance, effectiveness and efficiency in various fields of life of the state.

- Improve transparency, control and accountability of governance in order to implement the concept of Good Corporate Governance.

- Reduce significantly the total cost of the administration of relationships and interactions issued by governments and their stakeholders for the purposes of everyday activities.

- Provide an opportunity for the government to obtain new sources of revenue through its interaction with the parties concerned.

- Creating a new community environment that can accurately and quickly address issues faced in line with the various global changes and trends that exist.

- Empowering communities and other parties as a government partner in the process of making public policies equitably and democratically.

The implementation of e-government that dominated the world in the present form of the national population data integration and citizen registration services include the registration of births, marriages, deaths, change of address and for taxation. Here, the role of government as the main coordinator to create a governance environment. In order for the public service to be effective, there needs to be a boost to the government to immediately implement the egovernment (Shalahuddin and Rusli, 2005).[7]

The government can take advantage of the opportunities of the technology used in e-government, namely technology and communication, given the later communities have alternatives in accessing public services in traditional and modern. However, according to Indrajit $(2007 ; 7)$ there are two things that must be considered by the government when implementing e-government [8], which include:

- Community needs a top priority in government services. The government should no longer positioned as a dominant party, but considering his position as a service provider for its citizens.

- Availability of resources, both in terms of citizens and the government. Resources defined as skilled human resources and the availability of technology resources evenly.

\section{Constraint In Applying Electronic Government in Indonesia Government Environment}

As developing countries (the Third World), the use of e-government in Indonesia was not included encouraging. Not something new again if the Indonesian people still stuttering with developments in technology. The existence of the new technology used was limited to things that are entertainment only.

The average population of Indonesia are common in the technology development. And it can be said of e- government in Indonesia is still halfway and far below the required standards. There are problems faced in the implementation of e-government to improve governance. The main problem is the resistance and vacillation when addressing a new innovation to break old habits. There are three major aspects of the problem in the implementation of e-government (in Kumorotomo;2008). [9]

\section{Cultural Aspects}

- Resistance and rejection of society and the ranks of government officials towards e-government.

- Lack of awareness on the benefits and rewards of the technology used in e-government.

- reluctance to share data and information, so that the national integrated throughout the public service providers.

\section{Aspects of Leadership}

- Conflicting interests of central and local government level

- Regulations that have not been socialized and implementation is uneven.

- Allocation of budget for infrastructure development of public services that take advantage of e-government in APBN / APBD has not been a priority.

\section{Aspects Infrastructure}

- Existence of digital inequality that resulted in the uneven availability of information and communication technology infrastructure, as geographically spread throughout the islands of Indonesia.

- Availability of infrastructure for the provision of information and communication technology is still concentrated in large cities. Experts in remote areas are still very rare.

- The system of public services in Indonesia do not have a basic standard. This hampers the integration of population data and other documents of citizens nationwide.

To achieve the ideal conditions, should be improved concepts and strategies for the implementation of egovernment from all sides to improve the quality of government services environment. Besides the aspects mentioned above, the problem can also be seen from two sides, namely from the side of government and society. From government constraint identified is the quantity and quality of human resources (HR), facilities and infrastructure, and operational budgets. In terms of the public is the public mindset about information technology. Likewise with still many people who have not skilled to use the facilities of these technologies. 


\section{CONCLUSION}

E-government is not just a mere website, which contains information from the government, but also is a way towards good governance that provide public services in a fast, transparent and accountable. E-government aims to create public convenience in receiving the service.

The purpose of the implementation of e-government system is to improve the quality of public services. Egovernment can promote the establishment of governance that is transparent, accountable, corruption free, streamlined bureaucracy and increase the participation of citizens in control of governance. Good public services, effectively and efficiently can be a measure of the success of development in one country. Could it happen in Indonesia? The answer is very likely. Government needs to provide proportionally experts in the field of information and communication technologies in the body of government agencies and public service providers, as well as bridging the gap accessibility of technologies throughout the territory of Indonesia.

\section{References}

[1] Act No. 25 of 2009 on the Public Service.

[2] Hardiyansyah. "Quality Public Services: Concept, Dimension, Indicators and Implementation. Gava Media, Jogyakarta. 2011 Page 107.

[3] Hardiyansyah. "Quality Public Services: Concept, Dimension, Indicators and Implementation. Gava Media, Jogyakarta 2011 page 108.

[4] Kompas On Date 18 Mei 2005.

[5] Hardiyansyah. "Quality Public Services: Concept, Dimension, Indicators and Implementation. Gava Media, Jogyakarta 2011 page 109.

[6] Indrajit, Richardus Eko. "Electronic Government: Internet-Based Concept of Public Service and Information Technology." Aptikom 2006 Page 8

[7] Salahudin, M and A. Rusli. "Information Systems Planning for EGovernment in Indonesia Summarized Paper for of The Second International Conference on Innovation in Information Technology (IIT'05).

[8] Indrajit, Richardus Eko. "Electronic Government in Action: Implementation Strategies in Various Countries". Aptikom 2007 Page 7.

[9] Kumorotomo, Wahyudi. "Failure Application of E-Government and Activities Unproductive the Internet. Accessed on October 5, 2017. 